\title{
Essay \\ Racial Passing off the Record: A Journey in Reconnection and Navigating Shifting Identities
}

\author{
Gabby C. Womack
}

check for

updates

Citation: Womack, Gabby C. 2022. Racial Passing off the Record: A Journey in Reconnection and Navigating Shifting Identities. Genealogy 6: 8. https://doi.org/ 10.3390/genealogy6010008

Received: 20 October 2021 Accepted: 12 January 2022 Published: 18 January 2022

Publisher's Note: MDPI stays neutral with regard to jurisdictional claims in published maps and institutional affiliations.

Copyright: (C) 2022 by the author. Licensee MDPI, Basel, Switzerland. This article is an open access article distributed under the terms and conditions of the Creative Commons Attribution (CC BY) license (https:// creativecommons.org/licenses/by/ $4.0 /)$.

\author{
McQuade Library, Merrimack College, North Andover, MA 01845, USA; womackg@merrimack.edu
}

\begin{abstract}
Anyone of African descent or with African ancestry who engages in a genealogy project soon learns that the U.S. Census is a helpful yet frustrating tool. In 2016, equipped with my history degree and an online ancestry search engine, I searched for my great-grandfather Leroy in census records after I saw a picture of him as a young man at work in Philadelphia. This image would have been unremarkable had it not been for the fact that my African American ancestor was so light skinned that he seemed to blend in with his co-workers at Kramer's Fruit and Vegetables. I thought there had to be a story behind this. Classified as, "Mu", for mulatto in most of his records, Leroy became "Black" on the census in 1930. My first thought was to question whether this categorization changed for other folks like him. My research led me to my master's thesis "From 'Mulatto' to 'Negro': How Fears of 'Passing' Changed the 1930 United States Census". Through this research, I also became closer to my father's family. This piece will take you through this journey of discovery and my frustrations along the way.
\end{abstract}

Keywords: African American family; African American ancestry; African American history; passing; united states census; mulatto; mixed-race

\section{Introduction}

Race is one of the determinants of how far back people can follow their ancestors through the United States census. Many Black Americans struggle to obtain information on their ancestors before 1865 due to enslavement (Hyland 2020). However, the census has added and removed racial categories since 1790, which makes this research harder still (Bennett 2000). Racial categories have been a topic of interest in works such as Shades of Citizenship by Melissa Nobles, What is your Race? by Kenneth Prewitt, and "Racial Reorganization and the United States Census 1850-1930: Mulattoes, Half-Breeds, Mixed Parentage, Hindoos, and the Mexican Race", by Jennifer L. Hochschild and Brenda M. Powell (Hochschild and Powell 2008). Regarding racial passing, each of these sources connect the U.S. Census Bureau's removal of the "mulatto" category to the lack of information gleaned from that data point, segregation, and the growing "anxieties" of white people losing power. My thesis argued that it was full-blown fear that public officials, eugenicists, and white society held of racial passing. Further, these works do not comment on the effects of this erasure of mixed-race identities on the descendants of "near whites". This piece explores the difficulties of my genealogical research and how I learned to piece together my ancestor's story using the historical context of his time.

\section{In the Beginning}

The first time I saw the photograph of my great grandfather Leroy, it was on my paternal aunt's social media. This was the first time I had heard about him or seen a photo of him. Although I knew that many of my paternal family members were light-skinned Black folks, I did not realize that any of them could blend in with white people the way that Leroy seemed to be in this image. He stood outside of Kramer's Fruit and Vegetables with his white co-workers in 1926 Philadelphia. I searched for Leroy in census records online 
and, as I skimmed the results, I noticed that his race had changed from "Mu" to "Negro" in 1930.

A year or two after I saw that photo, I visited my paternal grandmother and we got to talking about our family tree and showed me some more photos of her father when he was a young man. She explained that her father didn't claim to be white, he just did not correct white folks if they made that assumption in order to get and keep jobs. Leroy was passing for his own survival and that of his family.

We continued discussing her father's family through correspondence, and I connected with my great aunt for her insight, as well. My grandmother later shared emails she received from another family member about our ancestors' surnames being in a pamphlet, (Surnames, by Counties and Cities, of Mixed Negroid Virginia Families Striving to Pass as 'Indian' or White by Walter A. Plecker ca. 1943 n.d.). This intrigued me, and I began searching for the document.

Sure enough, I found our ancestors' surnames and decided to do some digging on Walter A. Plecker. He was tied to much of my historical research on race in the United States in the early 20th century. Plecker was an advocate for the Racial Integrity Act of 1924, which prohibited interracial marriage, created strict lines of racial identification, and made it a crime to falsify one's racial category on government documents (Nobles 2000, pp. 31-42). This information tied in with my research on why the United States Census Bureau changed the racial classification of mixed-race people with African ancestry from "mulatto" to "negro" in the 1930 census (Womack 2017).

My professor Dr. Laura Prieto pointed me in the direction of A Chosen Exile: A History of Racial Passing in American Life by Allyson Hobbs which helped me learn about the lives of people who passed for white, what they lost, and what their families lost due to their decisions (Hobbs 2014). Hobbs emphasizes that passers often felt lonely when they removed themselves from their communities and chose to keep their identities secret. Their families were left with gaps in their daily lives and their descendants, with holes in their family trees. I placed my own family's story among these narratives and gained perspective on the experiences of Black folks throughout the 20th century.

I was aware that racial passing existed long before due to stories such as that of Ellen and William Craft (Craft and Craft 1999). Ellen passed as a white slaveholder with her husband William Craft as her body servant so that they could escape enslavement. The more research I did, I began to add information on the history of Black to white racial passing. My research included people in New England, such as Lemuel Haynes, a clergyman who fought in the Revolutionary War (Saillant 2003), Patrick F. Healy, a formerly enslaved man that became a priest and president of Georgetown University (O'Toole 2003), and Anita Hemmings, the first unofficial Black graduate of Vassar College (Sim 1999). According to her descendent Jillian Sim, Hemmings was possibly directly related to the Hemings of Monticello through Peter Hemings, Sally Hemings's brother.

\section{Diving Deeper}

Originally, I began this research hoping to find out why my great-grandfather's racial classification changed from "mulatto" to "negro", but searching for this reasoning, I found academic articles that attributed this transition to growing anxieties around racial identity and race mixing. The more I investigated the historical context of the early twentieth century, however, it seemed that the census changed its racial categories due more to a fear of losing power that many white people attributed to white superiority (Womack 2017).

With the eugenics movement on the rise, other influential figures shared Plecker's white supremacist views. Madison Grant (1921) and Lothrop Stoddard wrote books describing the inferiority of non-whites, how race-mixing would create "mongrels", and warned of the increasing populations of people of color (Stoddard 1921). I could see how these men and their works had influenced public opinion and political discourse as laws against interracial marriage spread across the country. 
As I read page after page of white supremacist rhetoric, I wondered why the mixedrace category was created in the first place. It seemed odd that the United States had this classification despite society's belief in white superiority and aversion to race-mixing. So, I began searching further back in history for the origins of the "mulatto" census category and found it in 1850 (Nobles 2000, p. 35). Josiah Nott believed that since Black people were inferior, those born from racial mixing would likely be infertile like a mule. He convinced a US Congressman to suggest that "mulatto" be added to the race category on the census to study the results. Nott developed his theory amid arguments about whether Black people and white people developed from the same origin and the implications that would have on slavery (Nott and Gliddon 1854).

Despite this attention to racial categorization, African Americans could be classified differently depending on their location within the United States. These inconsistencies were already confusing and became more difficult to use for census takers when the census added "quadroon", one-fourth Black ancestry, and "octoroon", one-eighth Black ancestry, in 1890 (Prewitt 2013, pp. 56-59; The New York Times 1910). Between 1910 and 1930, some states adopted "one-drop" statutes which claimed that a person with at least one drop of "Black" blood would be considered Black (Nobles 2000; Racial Integrity Laws (1924-1930) (Racial Integrity Laws (1924-1930) 2017). I saw that the discrepancies could be an issue for researchers such as myself.

Although scientific racism and the eugenics movement gave me an understanding of the views of people within academia and government agencies, I believed that the erasure of this category would have also required the support of the public. I reasoned that one way to find out what American society thought of racial passing was to see how often the topic was covered in the media (specifically in newspapers, films, and books). I used historical newspaper databases to look through articles in big newspapers from 1910 to 1929 and found many headlines implying that racial passing was a phenomenon fueled by what would later be known as the 'Great Migration'. There were also many news stories about court cases where white men claimed to have been "duped" by their wives (The New York Times 1924).

One such case was Rhinelander v. Rhinelander. Leonard Kip Rhinelander was a white New Yorker from a wealthy family who married Alice Jones in secret since she was mixed-race (Smith-Pryor 2009). When his family found out, his father pushed Rhinelander. Rhinelander pursued an annulment on the grounds that he didn't know that his wife was a "mulatto". The case proved that he did. I followed this case through more than one hundred New York Times articles from 1924 to 1925. This coverage, as well as the other articles, made me confident that racial passing was seen as scandalous, and that white people were afraid of being tricked into tainting their whiteness in such a way.

To confirm my theory, I decided to investigate how many books discussed or featured racial passing from 1900 to 1930. My hope was that I would see how popular this topic was based on how many books were published before the census change. According to my research, "at least eight novels were published with stories about or including characters passing for white" between those years. This seemed like a small amount, until I realized that six of the books were published between 1920 and 1930. Many of the books encouraged mixed-race people to claim their blackness and stick with Black people or their lives would fall into ruin or worse (Larsen 2007). Nella Larsen's Passing (1929) depicts the emotional loss that passers felt after separating themselves from their families, friends, and Black culture.

Films about racial passing stayed close to the same themes of the literature of the 1920s. I analyzed four films between 1930 and 1949, to see if racial passing was still a topic of concern after the census change and found that it was. I struggled to get a hold of the first film, "Veiled Aristocrats" by the Black director Oscar Micheaux since the full version was nowhere to be found (Micheaux 1932). In this film, the main character Rena's mother insists that it is best to pass for white to benefit from whiteness. Rena tries to do so, but ultimately feels that she must be true to herself. The version I purchased only ran about 48 
minutes long and had harsh edits. Micheaux was the only filmmaker in my list who was Black and employed an "all colored cast" for his passing film. One of the films, "Imitation of Life", was so popular that it was remade in 1959 (Stahl 1934). In this classic story, a white widowed mother takes in a Black single mother and her light-skinned daughter Peola. Peola is ashamed of her blackness and passes for white. Despite the popularity of some of these films, they still faced censorship, as the census was not the only measure taken in preventing race mixing during segregation (McGehee 2006). There were codes that prohibited any interracial romances or insinuation of interracial relationships in films. Some of the films faced more barriers than the others. "Lost Boundaries", a film based on a real family in Keene, New Hampshire that passed for white for twenty years, was not allowed to be shown in Atlanta since it appeared to promote integration (Werker 1949; Lost Boundaries Becomes a Censorship Test Case n.d.).

Each step of the way, the documents, books, articles, and films on race and racial passing were predominantly written and/or created by white Americans and therefore, may have projected their fears. Fears that the population of people of color in the United States was increasing rapidly and a loss of control over positions of power. Both of which, are echoed in white supremacist rhetoric today.

\section{Challenges}

Through my research process, I came up against many challenges using census records due to name changes or misspellings, inconsistencies of racial categorizations, and date restrictions. It is common for names to differ in government documents due to misunderstandings and census takers' interpretation of any person's identity. Census takers were also expected to record each person's race based on their own observations of how much "black blood" they had. They used categories such as "mulatto", "quadroon", and "octoroon" to describe persons with varying degrees of blackness (Prewitt 2013, pp. 56-59). Along with keeping track of the inconsistencies in names and race, I also had to maneuver around the lack of records from 1890 and inability to access those taken after 1940 due to the "72-year-rule" (History: The '72-Year Rule' n.d.). "Most of the 1890 census' population schedules were badly damaged by a fire in the Commerce Department Building in January 1921" (History: Why Can't I Find 1890 Census Records? n.d.).

Alongside his race, my great grandfather's name changed from Leroy to Roy in his census records. Despite the name change, I could see that he had not chosen to officially pass for white as the rest of his information stayed the same and his racial classification became "negro". However, Anita F. Hemmings' records were a bit harder to track down as she changed her name to Anita H. Love, moved to New York, and began being classified as "white" on the census. Her descendent, Jillian Sim only found out that she had African American ancestry after her grandmother Ellen Love, Hemmings's daughter, passed away. Until that point, Sim was under the impression that her family was just like any other white family in the United States (Sim 1999). Hemmings's choice to pass for white meant that her descendants might never truly understand their family history or their ancestors as people.

Both Leroy and Anita may have felt that they had to live a double life for their families to survive and succeed. This meant that they could not fully share themselves with their children and grandchildren. My great-grandfather likely faced the pain of this alone.

\section{Conclusions}

Through this research, not only did I gain even more understanding of why people passed for white and what that meant for their lives and the lives of their descendants, but I also realized that the U.S. Census change created a hurdle that many people cannot clear. One could be attempting to recreate their family tree only to see that one branch is impossible to find since their ancestor was classified as only white or only Black, thus creating an illusion of purity for white folks and disconnect for Black people. Many African Americans are faced with incomplete family trees and histories due to this erasure of mixed-race identity, as well as the lack of detailed record keeping during our ancestors' 
enslavement (Parker et al. 2015). Thus, people who search for their African American ancestors may hit this roadblock on top of many others.

Had it not been for my paternal aunt, grandmother, and great-aunt, I would not have been able to track down Leroy and make the connections between my family, government documents, and where we stand in the legacy of this country. Not only does this erasure result in an incomplete understanding of African American ancestry, but it also contributes to an inaccurate history of the United States. Removing the "mulatto" category allowed White people to simply pretend that whiteness was never threatened by mixed-race people and racial passing, leaving present-day society to uncover the truth.

Funding: This research received no external funding.

Institutional Review Board Statement: Not applicable.

Informed Consent Statement: Not applicable.

Acknowledgments: Thank you to Shannon Butler-Mokoro, for notifying and encouraging me to write for this special issue.

Conflicts of Interest: The author declares no conflict of interest.

\section{References}

Bennett, Claudette. 2000. Racial Categories Used in the Decennial Censuses, 1790 to the Present. Government Information Quarterly 17: 161-80. [CrossRef]

Craft, Ellen, and William Craft. 1999. Running a Thousand Miles for Freedom: The Escape of William and Ellen Craft from Slavery. Athens: University of Georgia Press.

Grant, Madison. 1921. The Passing of the Great Race or the Racial Basis of European History, 4th ed. New York: Charles Scribner's Sons.

History: The '72-Year Rule'. n.d. United States Census Bureau. Available online: https:/ /www.census.gov/history/www/genealogy/ decennial_census_records/the_72_year_rule_1.html (accessed on 21 September 2021).

History: Why Can't I Find 1890 Census Records? n.d. United States Census Bureau. Available online: https:/ /www.census.gov/ history/www/faqs/genealogy_faqs/why_cant_i_find_1890_census_records.html (accessed on 21 September 2021)

Hobbs, Allyson. 2014. A Chosen Exile: A History of Racial Passing in American Life. Cambridge: Harvard University Press.

Hochschild, Jennifer L., and Brenda M. Powell. 2008. Racial Reorganization and the United States Census 1850-1930: Mulattoes, Half-Breeds, Mixed Parentage, Hindoos, and the Mexican Race. Studies in American Political Development 22: 69-70. [CrossRef]

Hyland, David. 2020. Facing Challenges, Genealogist Offers Ideas to Trace African American Family Histories. The Morning Show. Madison: Wisconsin Public Radio (WPR).

Larsen, Nella. 2007. Passing. A Norton Critical Edition. New York: W.W. Norton \& Company, Inc.

Lost Boundaries Becomes a Censorship Test Case. n.d. Johnston Family Papers. Keene: Historical Society of Cheshire County.

McGehee, Margaret T. 2006. Disturbing the Peace: Lost Boundaries, Pinky, and Censorship in Atlanta, Georgia, 1949-1952. Cinema Journal 46: 23-51. [CrossRef]

Micheaux, Oscar. 1932. Veiled Aristocrats. Chicago: Micheaux Film Corporation.

Nobles, Melissa. 2000. Shades of Citizenship: Race and the Census in Modern Politics. Stanford: Stanford University Press.

Nott, Josiah C., and Geo R. Gliddon. 1854. Hybridity of Animals, Viewed in Connection with Mankind. In Types of Mankind: Or, Ethnological Researches, Based Upon the Ancient Monuments, Paintings, Sculptures, and Crania or Races and Upon Their Natural, Geographical, Philological and Biblical History. Philadelphia: Lippincott, Grambo \& Co.

O'Toole, James M. 2003. Passing for White: Race, Religion, and the Healy Family, 1820-1920. Boston: University of Massachusetts Press.

Parker, Kim, Juliana Menasce Horowitz, Rich Morin, and Mark Hugo Lopez. 2015. Chapter 1: Race and Multiracial Americans in the U.S. Census. Multiracial in America. Pew Research Center. Available online: https://www.pewresearch.org/social-trends/2015 /06/11/chapter-1-race-and-multiracial-americans-in-the-u-s-census / (accessed on 21 September 2021).

Prewitt, Kenneth. 2013. What's Your Race: The Census and Our Flawed Efforts to Classify Americans. Princeton: Princeton University Press.

Racial Integrity Laws (1924-1930). 2017. In Encyclopedia Virginia. Available online: http:/ / www.encyclopediavirginia.org/Racial_ Integrity_Laws_of_the_1920s (accessed on 21 September 2021).

Saillant, John. 2003. Black Puritan, Black Republican: The Life and Thought of Lemuel Haynes, 1753-1833. Religion in America Series. Oxford: Oxford University Press.

Sim, Jillian A. 1999. Fading to White. American Heritage 50: 68.

Smith-Pryor, Elizabeth M. 2009. Property Rites, 1st ed. Chapel Hill: University of North Carolina Press.

Stahl, John M. 1934. Imitation of Life. Universal City: Universal Pictures.

Stoddard, Lothrop. 1921. The Rising Tide of Color against White World Supremacy, 1st ed. New York: Charles Scribner's Sons. 
Surnames, by Counties and Cities, of Mixed Negroid Virginia Families Striving to Pass as 'Indian' or White by Walter A. Plecker ca. 1943. n.d. Encyclopedia Virginia. Available online: https://encyclopediavirginia.org/entries/surnames-by-countiesand-cities-of-mixed-negroid-virginia-families-striving-to-pass-as-indian-or-white-by-walter-a-plecker-ca-1943 (accessed on 21 September 2021).

The New York Times. 1910. Color Line in Census. The New York Times, January 4.

The New York Times. 1924. Rhinelander Sues to Annul Marriage: Alleges Race Deceit. The New York Times, November 24.

Werker, Alfred L. 1949. Lost Boundaries, Film Classics.

Womack, Gabrielle C. 2017. From 'Mulatto' to 'Negro': How Fears of 'Passing' Changed the 1930 United States Census; Boston: Simmons University. Available online: http:/ / proxy3.noblenet.org/login?url=https:/ /www-proquest-com.proxy3.noblenet.org/ dissertations-theses / mulatto-negro-how-fears-passing-changed-1930/docview / 1954049630/se-2?accountid=40663 (accessed on 21 September 2021). 